\title{
Women Petty Trading and Household Livelihood in Rural Communities in South-Eastern Nigeria
}

\author{
Okoro, Deborah $\mathbf{P}^{1^{*}}$, Mmamel, Zita $\mathbf{U}^{2}$, Okolo, Victor $\mathbf{O}^{3}$, Obikeze, Chinedum $\mathrm{O}^{4}$ \\ ${ }^{I}$ Department of Marketing, University of Nigeria Nsukka, Enugu Campus. \\ ${ }^{2}$ Department of Marketing, Institute of Management and Technology, Enugu. \\ ${ }^{3}$ Department of Marketing, University of Nigeria Nsukka, Enugu Campus. \\ ${ }^{4}$ Department of Marketing, Chukwuemeka Odumegwu Ojukwu University, Uli.
}

*Corresponding Author: Okoro, Deborah P, Department of Marketing, University of Nigeria Nsukka, Enugu Campus.

\begin{abstract}
This study sought to determine the effect of women petty trading and household livelihood in rural communities in southeastern Nigeria. Specifically, the research objectives intend to determine the contributions of rural women to household income, to identify the constraints faced by women in household livelihood and to determine the effect of women petty trading on household expenditure. The sample size of 400 was realized using Taro Yamane's formula at 5\% level of tolerance and $95 \%$ level of confidence. Instruments used for data collection were questionnaire and interview. The total number of 400 copies of questionnaire were distributed and returned. Survey method was adopted for the study. Three hypotheses were tested using descriptive and inferential statistical tool. The findings indicate that rural women contribute significantly to household income. Also, women faced significant constraints in household expenditure. And finally, women petty trading has a significant effect on household expenditure. The study recommends that government should encourage programmes that promotes women's economic rights and responsibilities and also reduce multiple taxes which they usually impose on them.
\end{abstract}

Keywords: Livelihood, Rural women, Household, Petty trading

\section{INTRODUCTION}

\subsection{Background of the Study}

The means by which women in rural communities gain income and meet basic needs are often met by multiple livelihood activities (Ayodepo, 2010). These activities can be termed the informal economic activities, and it serves as the most important source of employment in rural Nigeria. The sector is equally essential as it provides an opportunity for a large majority of rural population for selfactualization, self reliance and fulfillment (International Labour Organisation, 1990). The increasing detachment of women and children from men's income has led to an increase in the involvement of rural women in informal economic activities, hence according to Odejimi and Agbada (2014), the informal sector habours the highest number of active poor, who are small business owners that need financial assistance to sustain and develop their businesses. Rural women entrepreneurs by virtue of their location and level of education may have good business ideas but lack money to profitably use those ideas. Rural women activities mainly include petty trading, vocational enterprises, handicraft, farming and agro-processing (Onyenechere, 2011). Most low income women have important productive role in the family and also in the society. They are also involved in producing agricultural raw materials for our industries. In fact, most agricultural production and marketing activities including animal husbandry activities are performed by women.

According to Aspaas (1998) and Barret (1995), there is seemingly a good number of women in rural farming, processing and marketing. It is these income yielding informal economic activities by women that make them indispensable in the process of rural development and house hold sustainability. There is however, an observable change in the pattern of women's work in the recent times as their participation is declining in agriculture but increasing in petty trading; which according 
to Bryceson (2000) is called diversification out of agriculture. Thus, the emerging trend is that most men cannot provide for their families unaided; and thus rely on their wives for the household sustenance since women invest in their children's education and as a result boost their countries' overall economy (Kristof and Wudunn, 2009). Women's increasing participation in petty trading is also due to the global recession, and the current economic hardship in Nigeria. Further, Fapohunda (2012), stated that more than before, women are under increasing pressure to contribute to household income; this is even truer of women whose husbands have been laid off by the formal sector as a result of rationalization and privatization of public enterprises.

\subsection{Statement of the Problem}

Interestingly, women are seen all over the world as house makers, the keepers of the family, responsible for well-being of their children and husbands. Women often feel powerless and yet are willing to undertake considerable risk in order to provide for their children. In their desperation to keep the family together and provide food for their children, poor women have emerged in large numbers in the rural communities despite the risk and discrimination they face in the society. While men are likely to spend significant portion of their income for personal use like smoking, drinking, gambling etc, the women in the rural communities seem to devote some of their income to the family for food, medical treatment, school fees and clothing for their children. This simply means that women are likely to do jobs considered too demanding by men to ensure that their children survive. As men become unemployed and under- employed, households increasingly depend on women's income in petty trading, which are often considered marginal or degrading. How this income from women petty trading effect household livelihood constitute the problem to be addressed in this study.

\subsection{Objective of the Study}

The main objective of this study is to determine the effect of women petty trading and household livelihood in the rural communities in southeast Nigeria. Specifically, the study looked at the following sub-objectives:

1. To determine the contributions of rural women petty trading to household income.

2. To identify the constraints faced by women petty trading in household livelihood.

3. To determine the effect of women petty trading on household expenditure.

\subsection{Research Hypotheses}

In consistence with the objectives of the study and research questions, the following null hypotheses were tested for the purpose of the study:

1. Women petty trading does not make any significant contributions to household income.

2. There is no significant constraints faced by women petty trading in household livelihood

3. Women petty trading does not have any significant effect on household expenditure.

\section{LITERATURE REVIEW}

\subsection{Petty Trading}

Petty trading is commonplace in Africa and petty traders are found in semi-urban areas peddling garden produce and consumer goods imported from foreign countries (Bulty and Tulu, 2016). This form of trade takes place in both local and urban areas of the African countries (Hamat, Malek, Leng, Gopal and Husain, 2014). Although men are equally engaged in petty trading (Amrevurayire and Ojeh, 2016), rural women are mostly found engaging in petty trading (Abdullah, Ibrahim and King, 2010). Children petty traders or hawkers are frowned at, as it is being seen as child labour (Ampomah, 2012).

Petty trading is a small scale and informal economic activity that generates minimal income as it requires a small amount of an individual's income to operate (Hamat et al., 2014). It refers to the buying and selling of goods and services such as agricultural and consumer goods in smaller quantities (Mbisso, 2011). It is an economic activity that involves individuals with small financial base who struggle to eke out a living by growing their small businesses into bigger ventures (Agyeman, 2015). Those who engage in petty trading are known as petty traders.

This form of trading has contributed to the economic emancipation of the poor in Africa and had contributed to poverty alleviation of majority of the women in local communities (Bonkat, 2014; 
Agyeman, 2015). In line with this, Bulty and Tulu (2016) stated that it increases the economic viability of women. Similarly, Hamat et al. (2014) argued that although a small amount is required to kick-start a petty trade, it generates profit to guarantee growth and success. Conversely, Mnyawi and Benedict (2014) revealed in their study that the income realized through petty trading is inadequate to cater for the various needs of the petty trader despite the success stories recorded from petty trading.

Further, women petty traders engage in food vending, sale of used clothes (second hand clothes), general merchandise and other trades (Mnyawi and Benedict, 2014). Petty trade participation by women has improved the availability of goods and services in smaller units, at the right places, right prices, right form, and at the right time (consumer product utilities) (Bulty and Tulu, 2016). Women petty trading improves the health services needs of the traders, satisfies their food requirements, and settles their housing needs including settling utility bills such as water and electricity bills (Mnyawi and Benedict, 2014).

\subsection{Problems of Women Petty Trading}

Women petty trading has grown in large number across the globe over the last decades and increasingly the entrepreneurial potentials of women have changed the rural economies in many parts of the world. However women encounter some problems in the course of their petty trading namely:

1. Inadequate finance: Access to finance is a key issue for women. Accessing credit, particularly for setting and starting petty trading is one of the major constraints faced by rural women. Women often have fewer opportunities than men in gaining access to credit for various reasons, including lack of collateral, an unwillingness to accept household assets as collateral. As a result of sociocultural position of woman in the society; especially the Igbo traditional society, women has no right to sell off private or communal to raise money to kick start business.

2. Lack of skills: According to Otoo (2012), women have lower education levels and professional experience than their male counterparts. Women lack management skills and competencies in finance and accounting which are key to improving access to finance. Furthermore, due to social and educational factors, they fear complicated bank procedures and lack confidence to deal with lending institutions and effectively convey their business proposals.

3. Lack of information: Women entrepreneurs often lack information on the existence of credit facilities, financial instruments and the borrowing conditions of financial institutions due to the believe that they are housewives and should be restrained from exposing themselves at will.

4. Lack of track records: Women petty traders usually have difficulties showing past business performance information or continuous business activity since they are often forced to interpret their careers to take care of their children and engage in other domestic chores.

\subsection{Women and Household}

The term household covers a wide range of residential forms, groupings of people and functions, making a universal definition of household difficult. A common definition is a group of people who pool their resources together to achieve a common goal (Robertson, 1984). Households may involve close family, wider kin networks and can include unrelated co-residents such as lodgers. According to Roberts (1991), the concept of family embodies a more complex set of relationships and normative assumptions when compared to households. Economists have tended to focus on the micro economics of households, looking at the bargaining power of their different members (Evans, 1993; Folbre, 1988; Kabeer 1994; Sen, 1990). The bargaining power of men and women in households is shaped by their actual and perceived breakdown position (Beall and Kanji, 1999).

Thus, Dasgupt (2009) asserted that an increase in women's market wages relaxes the family budgets constraints and thereby increasing the amount of consumption of goods the household can produce. Thus, the unitary model of household decision making provides a ground for assuming that an increase in women's income opportunities may improve their welfare as well, but does not imply that this will necessarily be the case.

Indeed, increased access to employment and income for women does not readily translate into an improved status or bargaining power for women. Instead involvement in economic activity is a necessary condition for the attainment of gender equity in the economic sphere. However, this is in itself not sufficient because not all economic activities are empowering women as additional measures 
are required to promote gender equity in other sphere such as legal and political aspects (Masika and Joekes, 2009). Moreso, women petty trading leads to improvement in the family care, health, nutrition and housing. This ultimately leads to the wellbeing of household members. According to Mbisso (2011), petty trading ensures sustainable livelihood if the financial compensations realized from it is adequate to cater for the minimum basic needs of the women and their household. When women are involved in petty trading, they are far more likely than men to spend their income on improving their children's future (food, education, healthcare, clothing and housing) (Kristof and Wudunn, 2009).

In addition, house expenditure patterns are different in male and female-headed households. Women allocate a larger share of their budget to food than men. A number of studies have documented the fact that women tend to allocate a larger of their own resources for food and other basic needs of their children and family (Kennedy and Peters 1992; Lloyd and Gage- Brandon 1993; Quisumbing, Brown, Feldstein, Haddad and Pena, 1995; and Handa 1996). Expenditures shares for health, utilities and household goods are significantly higher for female headed households. Women invest more resources for caring for themselves and their children by providing the basic necessities of food and clothing.

Moreover, there are significant differences in the major employment activities of men and women which affect the level of income earned in male and female-headed households (Levin, Maxwell, Klemesu, Ruel, Morris and Ahiadeke 1999). Livelihood strategies are based on production and exchanges of cash and goods between households. Across all categories of households, women's income- generating activities are heavily concentrated in petty trading. According to Singwane and Gama (2012), a livelihood comprises capabilities, assets and activities required for a means of living; hence household livelihood can be defined as access to income and resources to meet basic needs. This includes access to food, portable water, health facilities, educational opportunities, housing, as well as time for community participation and social integration. It is sustainable if it can cope with and recover from stress and shocks maintain its capabilities and assets and provide sustainable livelihood opportunities for the next generation (Frankenberger, Drinkwater and Maxwell, 2000).

Furthermore, UNICEF (2001) noted that poverty has many dimensions including poor access to public services and infrastructure, unsanitary surroundings, illiteracy and ignorance, poor health, insecurity, voicelessness and social exclusion as well as low levels of household income and food insecurity. These features, which are part of the social reality of the poor (women) in Nigeria tend to be mutually reinforcing trapping the poor in a vicious circle. In a situation of poverty, women are poorer than men due to socio-cultural constraints (Akinlo, 2000). Akinlo equally describes the poor as people that lack adequate food, shelter, education and health. The poor have extreme vulnerability to ill health, economic dislocation and natural disasters. They are often exposed to ill treatment by institutions of the state and society and are powerless to influence key decisions affecting their lives. When they are employed, they are overworked and underpaid. In Urban areas, they are mostly found living in slums, squatters, on the street; and may remain in penurious condition from birth to death.

The poverty situation of Nigerian women has gone from bad to worse due to the impact of corruption and bad governance (Muoghalu and Abrifor, 2012).

\subsection{Theoretical and Conceptual Framework}

For the purpose of this study, the feminist theory and neo-classical approach will be most appropriate. Feminism is a diverse collection of groups aimed in one way or the other at advancing the position of women. Feminist agree that something is amiss in the treatment of women. According to Stanley and Wise (1983) feminism is not only a set of belief but also a set of theoretical constructions about the nature of women's oppression and the part this oppression plays within social reality. Feminist analysis try to reveal how ideas of rurality are folded into the ways in which gender identities are constructed and reconstructed on a daily basis. However, the concept of neo-classical approach centers on gender relationship.

Petty trading can be referred to as an economic activity that involves selling and buying of goods and services in small scale, ranging from agricultural produce to imported goods (Mbisso, 2010). Petty trading activities can be perceived as a reflection of prevailing social-economic realities of presentday cities especially on developing countries. It can be argued that petty trading is a product of unprecedented urbanization especially the failure by the formal employment and income generating sector to cater for the low- income households (UN Habitat, 2009). 


\subsection{Empirical Review}

In a recent study conducted by Onyenechere (2011), many households are headed by women. Here, the woman is not the legal household head, she is often perceived as a dependent although she may for most of her adult life have primary if not total responsibility for financial as well as the organizational aspects of the household. Ako-nai, Ologunde, and Adekola (2010) also found in their study that through the increased earnings of women, they were able to augment their household upkeep vote; they became pillars of support for husbands hit by the never-ending spate of retrenchment exercise sometimes. The study also reveals that some women employ multiple mode of livelihood whereby they are neither fulltime government's workers nor full time traders. Mordi, Sampson, Singh and Okafor (2010) also observed that women are largely responsible for household tasks and raising of children.

\subsection{Methodology}

The study adopted survey method. Data for this study were collected from both primary and secondary sources; however primary source was the main source of data. Participatory rural appraisal (PRA) technique was employed in the primary data collection. The geographical coverage of this study is Southeast Zone of Nigeria, comprising Abia State, Anambra State, Eboyi State, Enugu State and Imo State. The study was conducted in two randomly selected states, Enugu and Abia. The population of this study comprised all the 3,122,877 (Three million, one hundred and twenty-two thousand, eight hundred and seventy- seven) women in the two randomly selected South-eastern states namely, Abia and Enugu States. The table below summarizes the population of males, females and children in all the five South-eastern states including Abia and Enugu states.

Table1. National Census Estimate for South - Eastern States 2006

\begin{tabular}{|l|l|l|c|}
\hline State & Male & Female & Children \\
\hline Imo & $1,976,471$ & $1,951,092$ & $3,927,563$. \\
\hline Ebonyi & $1,064,156$ & $1,112,791$ & $2,176,947$. \\
\hline Enugu & $1,596,042$ & $1,671,795$ & $3,267,837$ \\
\hline Abia & $1,430,298$ & $1,451,082$ & $2,881,380$ \\
\hline Anambra & $2,117,984$ & $2,059,844$ & $4,177,828$ \\
\hline Total & $8,184,951$ & $8,246,604$ & $16,431,555$ \\
\hline
\end{tabular}

Source: National population census 2007

\subsection{Sample Size Determination}

Sample size in this study was determined using Taro Yamane's formula for finite population. The mathematical formula is given as:

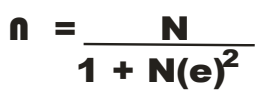

Where $\mathrm{n}=$ the sample size

$\mathrm{N}=$ total or finite population of the study area

$\mathrm{e}=$ level of significance (Limit of tolerable error)

$1=$ unity (constant)

$\begin{array}{rll}\mathrm{n} & = & \frac{3,122,877}{1+3,122,877(0.05)^{2}} \\ \mathrm{n} & = & \frac{3,122,877}{1+3,122,877(0.0025)} \\ \mathrm{n} & = & \frac{3,122,877}{1+7807.195} \\ \mathrm{n} & = & \frac{3,122,877}{3808.195} \\ \mathrm{n} & = & 399.948644 \\ \mathrm{n} & = & 400\end{array}$




\begin{tabular}{|c|c|c|c|}
\hline \multirow[t]{2}{*}{ Sample proportion for Enugu State $=$} & $1,671,795$ & $\mathrm{x} \underline{400}$ & $=214$ \\
\hline & \multicolumn{2}{|c|}{$3,122,877$} & 1 \\
\hline \multirow[t]{2}{*}{ Sample proportion for Abia State $=$} & $\underline{1,451,082}$ & $\mathrm{x} \underline{400}$ & $=186$ \\
\hline & \multicolumn{2}{|c|}{$3,122,877$} & 1 \\
\hline
\end{tabular}

\subsection{Sampling Procedure}

To make for good responses in the study, multi stage sampling was used to select the household samples. This involved both cluster and simple random samplings.

\subsection{Data Analysis}

Data were analyzed using both descriptive and inferential statistics. Objectives one(to determine the contributions of rural women to household income) and two (to identify the constraints faced by women in household livelihood)were achieved using descriptive statistics which include the use of tables, frequency counts, percentages, composite score, mean and standard deviation. Also objective three (to determine the effect of women petty trading income on household expenditure) was achieved by estimating a regression model, the regression model was specified explicitly thus:

A general Regression equation is put implicitly thus:

$A=a_{0}+a_{1} X_{1}+a_{2} X_{2}+a_{3} X_{3}+a_{4} X_{4}+a_{5} X_{5}+a_{6} X_{6}+a_{7} X_{7}+\mu$

Where

$\beta_{0}=$ Constant

$\mathrm{X}_{1}=$ Age

$\mathrm{X}_{2}=$ Marital Status

$\mathrm{X}_{3}=$ Household size

$\mathrm{X}_{4}=$ Level of Education

$\mathrm{X}_{5}=$ Employment Status

$\mathrm{X}_{6}=$ Petty Trading Income

$\mathrm{X}_{7}=$ Income from other sources

This equation was estimated for the three major household welfare measurement namely:

- Family consumption

- Health care services

- Basic Education.

3. RESUlts

Table1. Socio-economic Characteristics

\begin{tabular}{|l|l|l|l|l|l|}
\hline \multicolumn{2}{|l|}{ AGE } & Frequency & Percent & Valid Percent & Cumulative Percent \\
\hline Valid & Under 21 Yrs & 143 & 35.8 & 35.8 & 35.8 \\
\cline { 2 - 6 } & $21-49$ Yrs & 197 & 49.3 & 49.3 & 85.0 \\
\cline { 2 - 6 } & 50 Yrs\& Above & 60 & 15.0 & 15.0 & 100.0 \\
\cline { 2 - 6 } & Total & 400 & 100.0 & 100.0 & \\
\hline Educational Level & Frequency & Percent & Valid Percent & Cumulative Percent \\
\hline Valid & None & 101 & 25.25 & 25.25 & 25.25 \\
\cline { 2 - 6 } & Primary & 161 & 40.25 & 40.25 & 65.5 \\
\cline { 2 - 6 } & Secondary & 106 & 26.5 & 26.5 & 92 \\
\cline { 2 - 6 } & Tertiary & 32 & 8 & 8 & 100.0 \\
\cline { 2 - 6 } & Total & 400 & 100.0 & 100.0 & \\
\hline Marital & Status & Frequency & Percent & Valid Percent & Cumulative Percent \\
\hline Valid & Single & 22 & 5.5 & 5.5 & 5.5 \\
\cline { 2 - 6 } & Married & 310 & 77.5 & 77.5 & 83.0 \\
\cline { 2 - 6 } & Widow & 46 & 11.5 & 11.5 & 94.5 \\
\cline { 2 - 6 } & Separated & 22 & 5.5 & 5.5 & 100.0 \\
\cline { 2 - 6 } & Total & 400 & 100.0 & 100.0 & \\
\hline
\end{tabular}


Women Petty Trading and Household Livelihood in Rural Communities in South-Eastern Nigeria

\begin{tabular}{|c|c|c|c|c|c|}
\hline \multicolumn{2}{|c|}{ EMPLOYEMENT STATUS } & Frequency & Percent & Valid Percent & Cumulative Percent \\
\hline \multirow[t]{4}{*}{ Valid } & $\begin{array}{ll}\text { Government } & \text { Paid } \\
\text { Employment } & \end{array}$ & 32 & 8 & 8 & 8 \\
\hline & $\begin{array}{ll}\text { Private } & \text { Paid } \\
\text { Employment } & \end{array}$ & 59 & 14.75 & 14.75 & 22.75 \\
\hline & Self-employed & 296 & 74 & 74 & 86.74 \\
\hline & Full time Student & 13 & 3.25 & 3.25 & 100 \\
\hline \multicolumn{2}{|l|}{ Total } & 400 & 100 & 100 & \\
\hline \multicolumn{2}{|c|}{ Average Monthly income } & Frequency & Percent & Valid Percent & Cumulative Percent \\
\hline \multirow[t]{7}{*}{ Valid } & $500-999$ & 79 & 19.8 & 19.8 & 19.8 \\
\hline & 1000- 1499 & 45 & 11.3 & 11.3 & 31.0 \\
\hline & $1500-1999$ & 38 & 9.5 & 9.5 & 40.5 \\
\hline & $2000-2499$ & 53 & 13.3 & 13.3 & 53.8 \\
\hline & $2500-2999$ & 31 & 7.8 & 7.8 & 61.5 \\
\hline & 3000 and above & 154 & 38.5 & 38.5 & 100.0 \\
\hline & Total & 400 & 100.0 & 100.0 & \\
\hline \multicolumn{2}{|c|}{ Household size } & Frequency & Percent & Valid Percent & Cumulative Percent \\
\hline \multirow[t]{5}{*}{ Valid } & $1-4$ & 102 & 25.5 & 25.5 & 25.5 \\
\hline & $5-9$ & 211 & 52.75 & 52.75 & 78.25 \\
\hline & $10-14$ & 46 & 11.5 & 11.5 & 89.75 \\
\hline & $1-19$ & 25 & 6.25 & 6.25 & 96 \\
\hline & 20 and above & 16 & 4 & 4 & 100 \\
\hline \multicolumn{2}{|l|}{ Total } & 400 & 100.0 & 100 & \\
\hline
\end{tabular}

Source: Fieldwork, 2019

From the above result, 35.8 percent of the respondents are below 21 years while 49.3 percent are between $21-49$ years. Only 15 percent are above 50 years, this shows that women involved in petty trading in the study area are mostly those within their productive and active ages, about 25 percent of the women petty traders did not attend any formal school at all while about 40 percent finished first school leaving certificate, 27 percent completed secondary education while only 8 percent where able to attain post-secondary education. This shows that 75 percent of the women are literate about 6 percent of the respondents are single ladies while 78 percent are married, 12 percent are widowed and another 6 percent separated. Out of these respondents, 55 percent are fully petty traders, while 8perecnt are part-time that are employed by the government, 15 percent also have employment by private organizations and 3 percent are full time students. This shows that only about 11.25 percent of the rural women petty traders have other sources of income. The percentage distribution of the women by average monthly income shows that almost 20 percent earn less than 10,000 per month. also about 61 percent of the rural women petty traders earn less than 30,000 every month while on 39 percent earn 30,000 and above. This shows that the level of poverty among this group is still to some extent high. The result also shows that the study area has a large house hold size as 74 percent of the respondent came from households that are more from 5 persons and above. only 26 percent of the respondent mostly the younger ones who are still very active in child bearing or are yet to marry have household less than 5 person.

\subsection{Contributions of Rural Women to Household Income}

Table2. Distribution of women by major centres they spend their petty trading earning

Children's school fees $=1$, Family consumption =2, Hospital bills $=3$, Personal needs like clothes and jewelries $=4$, House rent $=5$

\begin{tabular}{|l|l|l|l|l|l|}
\hline \multicolumn{2}{|c|}{} & Frequency & Percent & Valid Percent & Cumulative Percent \\
\hline \multirow{5}{*}{ Valid } & 1.00 & 66 & 16.5 & 16.5 & 16.5 \\
\cline { 2 - 6 } & 2.00 & 231 & 57.8 & 57.8 & 74.3 \\
\cline { 2 - 6 } & 3.00 & 45 & 11.3 & 11.3 & 85.5 \\
\cline { 2 - 6 } & 4.00 & 31 & 7.8 & 7.8 & 93.3 \\
\cline { 2 - 6 } & 5.00 & 27 & 6.8 & 6.8 & 100.0 \\
\cline { 2 - 6 } & Total & 400 & 100.0 & 100.0 & \\
\hline
\end{tabular}

Source: Fieldwork, 2019

From the above we can see that bulk of the women, 58 percent spend the income generated from petty trading on family consumption, while almost 17 percent goes for school fees, while 11 percent are for 
hospital bills only 8 percent are used for personal needs of the women like clothes and jewelries etc while another 7 percent are spent on house rent. This shows that the income women generate from petty trading are mostly spent on the livelihood of the family as 93 percent are purely for the family needs and up keep.

Table3. Percentage distribution of women on frequency of Contribution for family upkeep

Daily=1, Weekly =2, Bi weekly =3, monthly =4, Bi-monthly =5, Quarterly =6, Annually =7

\begin{tabular}{|l|l|l|l|l|l|}
\hline \multicolumn{2}{|c|}{} & Frequency & Percent & Valid Percent & Cumulative Percent \\
\hline \multirow{5}{*}{ Valid } & 1.00 & 182 & 45.5 & 57.8 & 57.8 \\
\cline { 2 - 6 } & 2.00 & 12 & 3.0 & 3.8 & 61.6 \\
\cline { 2 - 6 } & 3.00 & 27 & 6.8 & 8.6 & 70.2 \\
\cline { 2 - 6 } & 4.00 & 60 & 15.0 & 19.0 & 89.2 \\
\cline { 2 - 6 } & 5.00 & 13 & 3.3 & 4.1 & 93.3 \\
\cline { 2 - 6 } & 6.00 & 11 & 2.8 & 3.5 & 96.8 \\
\hline & 7.00 & 10 & 2.5 & 3.2 & \\
\hline Missing & Total & 315 & 78.8 & 100.0 & \\
\hline Total & System & 85 & 21.3 & & \\
\hline
\end{tabular}

Source: Field work, 2019

The table above shows that most of the women about 46 percent contribute to the family upkeep daily while 15 percent contribute monthly, 21 percent have no regular way of contribution but in all, every women that is involved in petty trading has a lot of contribution to make for the family upkeep from the proceed of her petty trading business. About 3 percent contribute weekly while 7 percent contributes bi - weekly, other are 3 percent that contribute bi-monthly, another 3 percent quarterly and 2.5 percent annually.

\subsection{The Constraints Faced by Women in Household Livelihood}

Table4. Percentage distribution of the major challenges women face with their petty trading

\begin{tabular}{|l|l|l|l|l|}
\hline Challenges & Major & Manageable & Minor & Not at all \\
\hline & Percentage & Percentage & Percentage & Percentage \\
\hline Lack of capital to increase & 65 & 25 & 10 & 0 \\
\hline Wastages of products due to lack of patronage & 38 & 45 & 7 & 10 \\
\hline Involving children in petty trading & 52 & 29 & 11 & 8 \\
\hline Multiple government taxation & 89 & 8 & 3 & 0 \\
\hline Baby nursing and trading the same time & 32 & 24 & 21 & 33 \\
\hline Coping with a husband that is a drunk & 28 & 24 & 18 & 30 \\
\hline Helping the In-laws & 32 & 20 & 16 & 32 \\
\hline High cost of transportation & 75 & 15 & 5 & 5 \\
\hline
\end{tabular}

Source: Fieldwork, 2019

The table above and the chart below show the finding of the study on major challenges that petty trading women face while doing their day to day business. We discovered that 65 percent of the women have lack of capital as a major challenge to improving their business; only 25 percent see the challenge as manageable while 10 percent see the challenge as minor. In all the respondent opined that shortage of capital is a challenge they have to battle with day in and out.

Also another major challenge is multiple taxation, all the respondents complained of multiple taxation as an major issue, 89 percent of the respondent believe the livelihood of their household could be helped further if multiple taxation that take most of their income are dealt with 8 percent believe the taxes are manageable while only 3 percent see it as a minor challenge. Children involvement in the business is another challenge for about 52 percent of the women in petty trading as some send their children to hawk the wares and things like that, 29 percent believe that though involving the children may amount to child labour but it is still manageable, while 11 percent see the challenge as minor and 8 percent see it as no challenge at all. Against a priori expectation, baby nursing is not seen as serious challenge by many, 33 percent see no challenge in it while 24 percent see it as manageable 21 percent see it as minor challenge while only 32 percent think it is a major challenge. From this we can deduce that the major challenges faced by these women are dominantly multiple taxation, lack of capital, high cost of transportation and involving children in the operation of the business. 
Women Petty Trading and Household Livelihood in Rural Communities in South-Eastern Nigeria

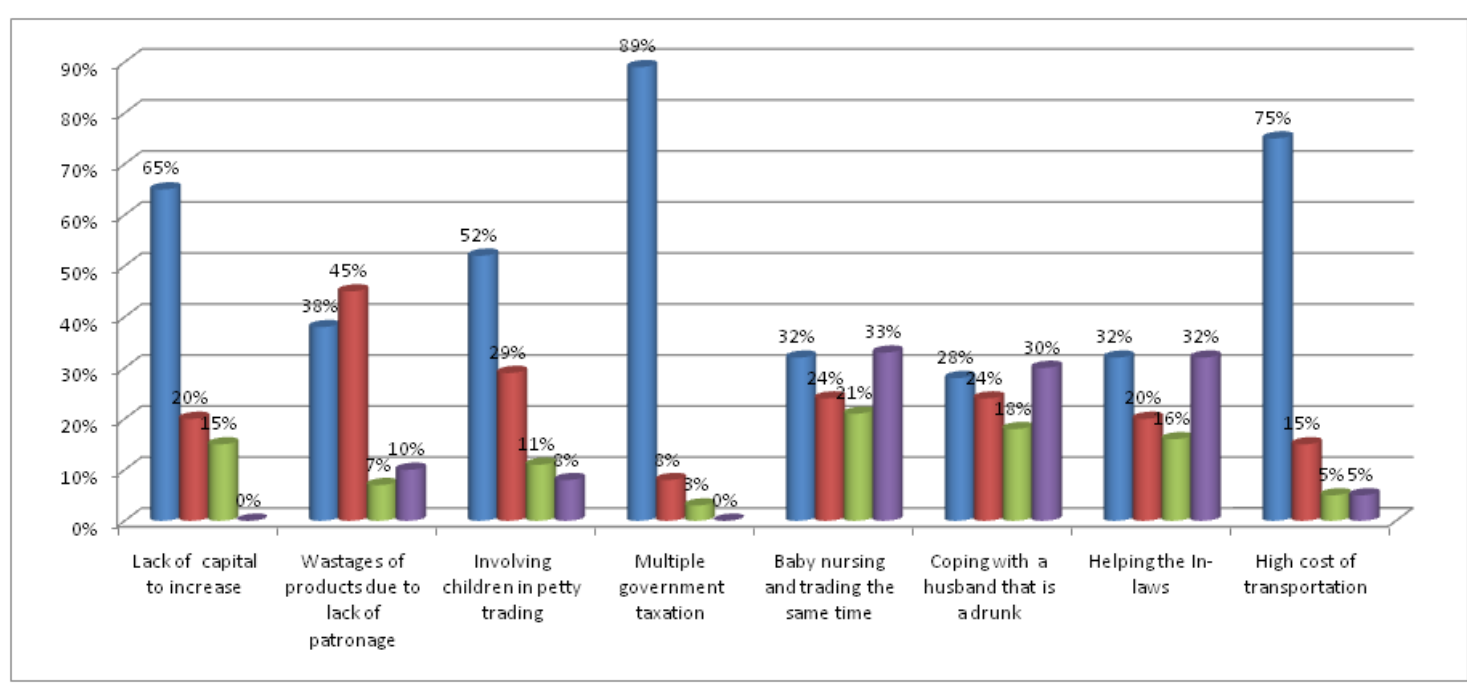

Source: Fieldwork, 2019

Table5. Determine the effect of women petty trading income on household expenditure

\begin{tabular}{|c|c|c|c|c|c|c|}
\hline \multicolumn{7}{|c|}{ Coefficients $^{\mathrm{a}}$} \\
\hline \multirow{2}{*}{\multicolumn{2}{|c|}{ Model }} & \multicolumn{2}{|c|}{ Unstandardized Coefficients } & Standardized & \multirow[t]{2}{*}{$t$} & \multirow[t]{2}{*}{ Sig. } \\
\hline & & B & Std. Error & Beta & & \\
\hline \multirow{8}{*}{1} & (Constant) & 3.259 & 1.518 & & 2.148 & .033 \\
\hline & AGE & -.655 & .217 & -.235 & -3.025 & .003 \\
\hline & MARST & .779 & .818 & .056 & .953 & 341 \\
\hline & EDU & .343 & .099 & -.227 & -3.452 & .001 \\
\hline & PINCOME & .241 & .059 & .271 & 4.096 & .000 \\
\hline & OTHERINCOME & 014 & .068 & -.012 & -.207 & 836 \\
\hline & HHSIZE &.-055 & .067 & .057 & .820 & 413 \\
\hline & EMPLOY & -.400 & .083 & -.301 & -4.834 & .000 \\
\hline \multicolumn{7}{|c|}{ a. Dependent Variable: FAMILY CONSUMPTION } \\
\hline \multirow{2}{*}{\multicolumn{2}{|c|}{ Model }} & \multicolumn{2}{|c|}{ Unstandardized Coefficients } & $\begin{array}{l}\text { Standardized } \\
\text { Coefficients }\end{array}$ & \multirow[t]{2}{*}{$\mathrm{t}$} & \multirow[t]{2}{*}{ Sig. } \\
\hline & & $\mathrm{B}$ & Std. Error & Beta & & \\
\hline \multirow{8}{*}{1} & (Constant) & 7.528 & 1.538 & & 4.894 & .000 \\
\hline & $\mathrm{AGE}$ & .210 & .209 & .069 & 1.006 & 316 \\
\hline & MARST & -2.815 & .796 & -.217 & -3.537 & .000 \\
\hline & EDU & .440 & .114 & -.283 & -3.864 & .000 \\
\hline & INCOME & .085 & .065 & .005 & .075 & 940 \\
\hline & OTHERINCOME & .177 & .102 & .112 & 1.732 & .084 \\
\hline & HHSIZE & -.078 & .069 & .082 & 1.124 & 262 \\
\hline & EMPLOY & .413 & .093 & .302 & 4.436 & .000 \\
\hline \multicolumn{7}{|c|}{ a. Dependent Variable: HEALTHCARE OF THE FAMILY } \\
\hline \multirow{2}{*}{\multicolumn{2}{|c|}{ Model }} & \multicolumn{2}{|c|}{ Unstandardized Coefficients } & $\begin{array}{l}\text { Standardized } \\
\text { Coefficients }\end{array}$ & \multirow[t]{2}{*}{$\mathrm{t}$} & \multirow[t]{2}{*}{ Sig. } \\
\hline & & $\mathrm{B}$ & Std. Error & Beta & & \\
\hline \multirow{8}{*}{1} & (Constant) & .973 & .291 & & 3.348 & .001 \\
\hline & AGE & .361 & .061 & .424 & 5.899 & .000 \\
\hline & MARST & .789 & .215 & .338 & 3.665 & .000 \\
\hline & EDU & .065 & .029 & -.136 & -2.255 & .025 \\
\hline & INCOME & .016 & .017 & -.055 & -.901 & 368 \\
\hline & OTHERINCOME & -.107 & .020 & -.276 & -5.485 & .000 \\
\hline & HHSIZE & -.088 & .019 & -.290 & -4.603 & .000 \\
\hline & EMPLOY & .058 & .024 & .134 & 2.374 & .018 \\
\hline
\end{tabular}

\section{Source: Spss}

The impact of the petty trading income on family consumption measured is tabulated above, the coefficient of petty trading income represented by PINCOME is positive with value .241 in this 
equation. Family consumption $=3.259+(-.655)$ Age +.779 Marital Status +.343 Edu +241 Pincom + .0140 therincome $+(-.055)$ HHsize $+(-.400)$ Employ. This implies that every one naira earned by the women petty traders that is spent on family consumption has the capacity of improving household consumption by .241 ; if all other factors are held constant. Hence, the income from women petty trading in the study area is very significant for the family consumption at 5 percent level of significance.

Also the impact of the petty trading income on family health care services shows thus:

Healthcare $=7.528+.210 \mathrm{Age}+(-2.82)$ Marital Status $+.440 \mathrm{Edu}+.085$ Pincom +.177 Otherincome $+(-.078)$ HHsize +413 Employ. Implying that at 5 percent significant level, PINCOME is 0.085 significant in taking care of the health of the household of women involved in petty trading.

On the other hand, the impact of the petty trading income on children education is measured thus:

Child Edu $=.973+.361$ Age +789 Marital Status +.065 Edu +.016 Pincom $+(-.107)$ Other income + $(-.088)$ HHsize +.058 Employ, showing that payment of children school fees is a major centre for expending the income from petty trading at 5 percent level PINCOM is 016 significant.

\subsection{Summary of Findings}

The result based on the descriptive statistics reveals the following;

1. Rural women contribute significantly to household income.

2. Women faced significantly lots of constraints in household livelihood.

3. Women petty trading significantly affects household expenditure

\section{CONCLusion}

Income from women petty trading is very important when it comes to household livelihood. Apart from the fact that it makes women to be independent, it equally helps them in taking care of household responsibilities. Women petty trading can be a source of support to various families if governments can encourage and assist them in petty trading.

However, the women in this study are not poor because they want to be poor, neither are they poor because they are idle or lazy. They can be regarded as a set of producers with resources so limited that their productivity and efficiency are undermined.

\section{RECOMMENDATION}

Based on the findings, the following recommendations were made:

1. Government should encourage programmes that promote women's economic rights and responsibilities and also reduce multiple taxes which they usually impose on them.

2. Vocational skills should be generated for the women in the rural communities and government should establish craft centers.

3. It is the women's expectation that the government should encourage development in every area of society.

4. A data bank should be created on all aspects of women's activities, to serve as a reference in policy making, monitoring and impact assessment.

\section{REFERENCES}

[1] Abdullah, Ibrahim and King, (2010). Women's voices, work and bodily integrity in pre-conflict, conflict and post-conflict reconstruction processes in Sierra Leone. IDS Bulletin, 41(2), 37-45.

[2] Agyeman, O. A. (2015). An evaluation of the impact of microfinance on petty traders: A case study of Kumasi central market. Master's Thesis. Ghana: Kwame Nkrumah University of Science and Technology.

[3] Akinlo, A. A, (2000). Strategy for poverty alleviation in Nigeria. A Paper Presented at National Workshop for Local Government Executives, Organized by Centre for Gender and Social Policy Studies, O.A.U, Ile Ife, Nigeria.

[4] Ako-nai, R. I., Ologunde, A. O. \& Adekola, O. G. (2010). Global integration, household survival, and economic empowerment of women in Osun State Nigeria. Journal of Nigeria Studies, 1(1), 1-24.

[5] Ampomah, F. (2012). Child labour in petty trading (hawking business) in Ghana: A case study of Madina and Abokobi areas in Ga East district. Master's Thesis. Norway: University of Bergen. 
[6] Amrevurayire, E. O., and Ojeh, V. N. (2016). Consequences of rural-urban migration on the source region of Ughievwen clan Delta State Nigeria. European Journal of Geography Volume 7(3), 42-57.

[7] Aspaas, H. R. (1998), Heading Households and Heading Businesses: Rural Keyan Women in the Informal Sector. The Professional Geographer, 50(2), 192-204.

[8] Ayodepo, O. G. (2010). Economic Activities and Copying Strategies among Female Agro-Pastoraists in Ogun State Nigeria.' Ozean Journal of Social Sciences, 3(2), 149-159.

[9] Barret, H. (1995). Women in Africa: The neglected dimension in development. Geography, 80(3), 21-24.

[10] Beall, J., \& Kanji, N. (1999). Households, Livelihoods and Urban Poverty, Background Paper for ESCOR Commissioned Research on Urban Development: Urban Governance, Partnership and Poverty.

[11] Bonkat, L. (2014). Survival strategies of market women and violent conflicts in Jos, Nigeria. Journal of Asia Pacific Studies, 3(3), 281-299.

[12] Bulty, B. G., and Tulu, D. T. (2016). The impacts of petty trade on household livelihood: A study of women petty traders in Oromia regional state, West Shoa zone. American Journal of Business and Management Vol. 5, No. 3, 2016, 113-117.

[13] Bryceson, D. (2000). Rural Africa at the Crossroad: Livelihood Practices and Policies. ODI Natural Resources Perspectives. Paper No 52, Africa Studies Centre Leiden University, Netherlands.

[14] Dasgupt, I. (2009). Women's Employment, Intra- Household Bargaining and Distribution: A Two-Sector Analysis. Retrieved 16/10/2019 from http: www. Nottingham.ac.uk/economics/credit/ research/ papers/ cp.99.5 pdf.

[15] Evans, A. (1993). Gender Issues in Rural Household Economies, IDS Bulletin, 22(1), 51-59.

[16] Fapohunda T.M (2012). Women and informal sector in Nigeria: Implications for development. British Journal of Arts and Social Sciences, 4(1)3, 5-45.

[17] Folbre, N. (1998). The Black Four of Hearts: Towards a New Paradigm of Household Economics, Standford: Standford University Press.

[18] Frankenberger, T., Drinkwater, M. \& Maxwell, D. (2000). Operationalizing household livelihood security: A holistic approach for addressing poverty and vulnerability, Retrieved 28/07/2019 from http:// www.Fao.org.

[19] Hamat, Z., Malek, N. M., Leng, K. S., Gopal, P. S., and Husain, A. S. (2014). An exploratory study on working capital management among petty traders in Kuala Nerang, Kedah. Journal of Human Capital Development, 7(2), 1-10.

[20] Handa, S. (1996). Expenditure behaviour and children's welfare: an analysis of female headedhouseholds in Jamaica. Journal of Development Economics, 50(1), 165-187.

[21] International Labour Organisation (1990). Women's employment promotion in Africa: Patterns and relevant issue, Geneva, Switzerland, Geneva Switzerland.

[22] Kabeer, N. (1995). Necessary, sufficient or irrelevant?, women, wages and intra household power relations in Bangladesh. IDS Working Paper, No 25, IDS, University of Sussex.

[23] Kennedy, E and Peters, P (1992). Influences of Gender of Head of Households on Food Security, Health and Nutrition. World Development, 20(8), 1077-1085.

[24] Kristof, N., \& Wudunn, S. (2009). Half the sky turning oppression into opportunity for women worldwide Retrieved 04/09/2019 from https://ssir.org > books > entry > half_sky_sheryl_wudunn_nicholas_kristof.

[25] Levin, C. E., Maxwell, D.G., Klemesu, M. A., Ruel, M. T., Morris, S. S., \& Ahiadeke, C. (1999). Working Women in Urban Settings: Traders, Vendors and Food Security in Accra.

[26] Lloyd, C.B., \& Gage- Brandon, A. J. (1993).Women's role in maintaining households: Family welfare and sexual inequality in Ghana. Populations Studies, 47(1), 115-131.

[27] Masika, R., \& Joekes, S. (2009). Employment and sustainable livelihood: Retrieved 13/10/2019 from http //www.nottinghan.ac.uk/economics/credit/research/papers/cp.99.5pdf.

[28] Mbisso, D. (2010). Petty trading in marketplaces, space generation, use and management at Temeke Stereo Marketplace in Dares Salaam, Tanzania.

[29] Mnyawi, S. P., and Benedict, G. (2014). Contribution of petty trade on household income poverty reduction: A case of Madukani ward, Dodoma region. International Journal of Innovation and Scientific Research, 6(2), 111-119.

[30] Moghalu, C. O., \& Abrifor, C. A. (2012). Urban poor women and governance in Nigeria. European Scientific Journal, 8(5), 1-10.

[31] Mordi, C., Sampson, R., Singh, S., \& Okafor, C. (2010). The role of cultural values in understanding the challenges faced by female entrepreneurs in Nigeria, gender in management. An International Journal, 25(1), 5-24. 
[32] Odejimi D. O., \& Agbada, A. O. (2004), Rural women entrepreneurship development in Ovia North East, Edo State, Nigeria: The case for microcredit, European Journal of Business and Management, 6(24), 136-141.

[33] Onyenechere, E. C. (2011). Spatial distribution of women informal economic activities in the rural areas of Imo State Nigeria. Journal of Geography and Regional Planning, (1), 20-35.

[34] Otoo, B. K. (2012). Micro- credit for micro- enterprise: A study of women petty traders in central region Ghana. International Journal of Scientific Research in Education, 5(3), 247-259.

[35] Quisumbing, A., Brown, L., Feldstein, H., Haddad, L., \& Pena, C. (1995). Women: The key to food security, food policy report, international food policy research institute, Washinghton, D.C.

[36] Roberts, B. R. (1991). Households Coping Strategies and Urban Poverty in a Comparative Perspective in Gottdiener, M., and Pickvance, C.G. (eds) Urban Life in Transition, Vol 39, Urban Affairs Annual Review, Sage, Newbury Park.

[37] Robertson, C. (1984). Sharing the same bowl: a socio-economic history of women and class in Accra, Ghana: Bloomington, India University Press.

[38] Sen, A. (1990). Gender and co-operative conflicts in tinker I persistent inequalities. New York: Oxford University Press.

[39] Singwane, S. S. \& Gama, M. (2012). Contribution of women employment on household livelihoods in Swaziland-the case of Zombodze Phasemdzimba community. Journal of Sustainable Development in Africa, 14(1), 59-75.

[40] Stanley, L., \& Wise, S. (1983). Breaking out, feminist consciousness and feminist research. London: Routledge and Kegan Paul.

[41] UN Habitat (2009). Global report on human settlement. London: Eastscan.

[42] UNICEF (2001). Women and children's rights in Nigeria: A wake up call, situation assessment and analysis. Retrieved 09/11/2019 from https://www.researchgate.net > publication , 260186830_UNICEF_2001_Ch.

Citation: Okoro, Deborah P, et.al. “ Women Petty Trading and Household Livelihood in Rural Communities in South-Eastern Nigeria " International Journal of Managerial Studies and Research (IJMSR), vol 8, no. 2, 2020, pp. 1-12. doi: http://dx.doi.org/10.20431/23 49-0349.0802001.

Copyright: () 2020 Authors. This is an open-access article distributed under the terms of the Creative Commons Attribution License, which permits unrestricted use, distribution, and reproduction in any medium, provided the original author and source are credited. 